\title{
Cacoepy (bad pronunciation or mispronunciation) of scientific terms and their effect on learning of secondary level science students
}

Arsalan Rasheed ( $\square$ arsalanrrasheed@gmail.com )

Government of Khyber Pakhtunkhwa https://orcid.org/0000-0001-8576-9289

Anita Awan

Government College University Faisalabad

\section{Research Article}

Keywords: cacoepy, scientific terms, secondary level, science education

Posted Date: November 17th, 2021

DOI: https://doi.org/10.21203/rs.3.rs-1058432/v1

License: @ (i) This work is licensed under a Creative Commons Attribution 4.0 International License. Read Full License 


\section{Abstract}

This research investigates cacoepy of science terminology encountered by the secondary level school students of Kohat district. The problem of cacoepy of scientific terms needs investigation due to the assumption that mispronunciations if learned in secondary level were still frequently performed by the advanced level students or may be throughout their life. The current research was designed in order to identify the cacoepy of common science terminologies by secondary school students and to study the science teachers' views on secondary level science textbooks produced by the Khyber Pakhtunkhwa Textbook board. It was found that majority of the students like science subjects and find the terminologies difficult in which most of the terms contain more than 7 alphabets and were considered as complex terms. Due to this complexity, students feel difficulty in learning of scientific terms. Most of science terms were derived from Greek, Latin and other ancient languages, so students cannot understand their meanings. Almost every chapter of secondary school biology, chemistry and physics is overloaded with difficult terms and students felt difficulty in preparation of those subjects in which mostly difficult terms were found in biology. Mostly science teachers emphasize goals for school science that are directed only toward preparing students for the next academic level (for further formal study of science) and finishing his course within session ignoring the students provnciationofscient if icter min ologies. Itisrecommendedtâuth or sshodusesimp $\leq$ terms and avoermsconta $\in \in$ gm or ethan $7 \alpha b e t s . i$

$s$ revision and insertion of high workload. Teachers should insert few terms into science lessons for practising daily, and it is enough to devote a minute or two to some pronunciation issue so that fluency during lecture is not interrupted a lot. Pointing out a pronunciation problem when it has just arisen in the course is a good way of introducing correct pronunciation into the class. English plays an important part in the development of students because of its present and future as an international language. Real life activities or examples should be associated with important topics. Textbooks should be altered for language of explanation to match the level of students in secondary schools in Khyber Pakhtunkhwa, and some outdated themes should be replaced with new themes to meet the needs of the 21 st century. It is suggested that the textbook board in Khyber Pakhtunkhwa should include the urdu phonology and meaning of the found terminologies at the start of each chapter.

\section{Introduction}

\section{Background of The Study}

This research investigates cacoepy of science terminology encountered by the secondary level school students of Kohat district. Pronunciation, defined by the Oxford English Dictionary, refers someone's competence in producing sound used to deliver meanings. Then, the study to find out pronunciation problems becomes necessary since secondary science education is the basic and it is one of the problems in students of KPK districts. Someone with inaccurate pronunciations might jumble sounds. As known that sound or combination of sounds are causing different meanings (Dardjowidjojo, 2009), it will, thus, lead the hearers to misunderstand what is being tried to deliver. Then, the hearers will misunderstand the speech because the speaker is unintentionally misleading the speech by performing mispronunciation.

The problem of cacoepy needs investigating due to the assumption that mispronunciations if learned in secondary level were still frequently performed by the advanced level students or may be their throughout life. Although they had been in the advanced level of speaking courses, they were still identified to perform mispronunciations. This research then tried to find out the cacoepy of scientific terms and their effect on learning of secondary level science students so that such pronunciation problems could be taken into account. This study will help those who are teaching or and studying science subjects in English as a second language by raising awareness of certain complicated scientific terms. The research will assist science teachers in addressing these terms and encourage students to practice further in order to achieve proper pronunciation. The finding of this research would also facilitate the textbook board in replacing complex science terminology with simple alternative words.

\section{Cacoepy}

Cacoepy means the bad pronunciation or mispronunciation of words (Wordsense, 2020; Wiktionary, 2019). According to Dictionary.com, "cacoepy means incorrect or mistaken pronunciation". The word "cacoëpy or cacoepy" (kuh-koh-uh-pee) is derived from ancient Greek kakós (kakos) which means "bad" and $\nabla \pi о \varsigma$ (epos) which means "word"). The first known use of cacoepy is 1840-45 (Dictionary.com) or 1854 (Merriam-Webster). Scientific terms, which plays a significant role in the teaching of research, is a part of the jargon that scientists use in their professional practises. The collection of science or technological words that typically originate from Greek and Latin roots and are used in different languages, sometimes with morphological alterations but with the same meaning can also be defined as scientific terms (American Heritage, 2016). Scientists often discover or generate new material or immaterial phenomena and ideas when observing nature and are forced to name them. Many of those titles are only known to clinicians. However, they are increasingly becoming part of modern languages and research courses due to the popularisation of science (Kuritz, 1981).

\section{Secondary education}

Secondary education is informally regarded as the education children receive during their teenage years, although the average ages of entrance and exit vary considerably among various nations. The distinction between lower secondary education and higher secondary education is useful in a global context, because developing countries are sometimes able to provide some access to lower-secondary education, while higher secondary education is still beyond the national reach. Lower-secondary education is considered to generally target eleven- to fifteen-year-old children, and upper-secondary education to target fifteen- to nineteen-year-olds (Serrant and McClure, 2001).

In the context of life-support systems, secondary education systems in both underdeveloped and developed nations will be considered in this article. The objective is to identify key aspects of secondary education that may be essential contributors to national self-sufficiency. There is danger in examining and evaluating national education systems in less-developed nations because it is too easy to reach the conclusion that they should mimic the education systems

Loading [MathJax]/jax/output/CommonHTML/jax.js 
of developed nations. In fact, attempts to emulate educational systems that have worked elsewhere may impede economic and social progress in a lessdeveloped nation (Eubanks \& Eubanks, 2000).

In developed countries, the education and training that children receive during their teenage years has long been recognized as crucial to development of job skills and other attributes that affect the ability to function productively as a member of society. In lessdeveloped countries, economic pressures typically force children into the workforce at a much earlier age (Puryear, 1995). Consequently, fewer individuals are well enough educated to make significant contributions to the economic and social development of their countries. Data from UNESCO and other international agencies suggest that some secondary education is becoming more widely available in some less-developed countries; however, the formal education of children in countries ravished by civil war, natural disaster, disease, or widespread economic hardship is often virtually nonexistent (UNESCO, 1997; 2000). As a world civilization, it is not clear that any significant progress is being made toward the education of the population.

Secondary education is always taken as first step towards getting the opportunities and enjoying the benefits of economic and social development. If quality education at secondary level will be made sure, it will drive the students a path of acquiring more education either academic or technical and it will have great impact on the enrolment not only at the levels below secondary level but above this level as well. Nothing by only quality education can make young generation better dedicated citizens of the society and drive the country towards the path of prosperity. More focus on the provision of quality secondary education has also become the demand of the time due to the fact that market is in demand of a more sophisticated labor force and only quality education at secondary level can help achieving this goal (Kazmi, 2016).

\section{Importance of science education}

This is an era of science and technology but numerous studies document that students' attitude towards science decreases with increase in grade levels (Francis \& Greer, 1999; Pell \& Jarvis, 2001) and this decline is more rapid in middle and high school years (Rani, 2000; Weinburgh, 1995; Anwer, et al., 2012). Usage of scientific methods, concepts, and scientific tools have become a global phenomenon. Scientific information is shared across the regions. Every object is described by specific word which helps in building concepts. Single word or group of words are helpful in concept formation of things when they are out of context. Scientific research is going on all over the world providing knowledge in all fields of life. Scientific knowledge is increasing at a tremendous rate as science unfolds knowledge about surroundings and diversity of life. Out of physical and natural field of science, the researcher selected the biological fields of natural sciences, because it is an ever-expanding area and is directly related to the branch of science dealing with real life (Kauser \& Shah, 2019).

In order to prepare children to embrace diversity in society, education plays an important role, particularly in recognising people with physical disabilities as equal contributors to society's growth and development, and a textbook is an effective tool to achieve this goal (Kivirauma \& Laitinen, 2014). Pakistan's education system is usually divided into six levels: pre-school (from 3 to 5 years of age), primary (from grade one to grade five), middle (from grade six to grade eight), high (from grade nine to grade ten, leading to a Secondary School Certificate or SSC), intermediate (from grade eleven to grade twelve, leading to a Higher Secondary School Certificate or HSSC), and university programmes leading to a University Certificate In Pakistan, secondary education starts at grade 9 and lasts for four years. Students are expected to pass a national examination conducted by the state Board of Intermediate and Secondary Education (or BISE) at the conclusion of each academic year. Students are required to take a standardised exam in each of the early sections of their academic subjects upon completion of grade 9. They again offer these assessments in the second sections of the same courses at the end of grade 10 . They are awarded a High School Certificate (or SSC) following satisfactory completion of these tests. This is called a "matriculation diploma" or "matric" for short locally. A mixture of eight classes, including electives (such as biology, chemistry, computer science and physics) and compulsory subjects (such as algebra, English, Urdu, Islamic studies and Pakistani studies), are typically included in the curriculum.

\section{Science Textbooks: A source for the transfer of knowledge}

The status of science education can be summarized in a single word-textbooks (Yager, 1983). Science is the facts and concepts included in a textbook. Textbooks determine the order, the examples, the applications of science topics that students experience. The major curriculum decision that most teachers make is the choice of a textbook; after such selection, they often lament, '-If only a better one could be found." The science curriculum is the content included in relatively few textbooks. Most all instruction in science is based on the information in a single textbook. Teachers seek safety in maintaining close alliance with a textbook. Teachers make textbooks the "answer place" for teacher questions-both those used in discussions and those used as examinations. The instructional sequence is dictated by a textbook; the typical sequence is assign, recite, test, discuss test. The content of science is restricted to that between two covers of a textbook. The teacher's power seems to rest with the information in the textbook. Teachers' questions focus on information in the textbook. A. V. materials are supplements to information in textbooks; at times they merely prove to be a means to present the same information as that in a textbook. Teachers appear to be imprisoned by the textbook.

There are many objects (living/non living) around us and each object is described by specific word. The need of information and understandable communication require specific designation to each item. This will lead to globalization and will help in global competition and global cooperation. Global communication is based on the vocabulary in all fields to convey the contents in meaningful ways. The vocabulary includes the words, concepts which ultimately in confined form, become specific terms. The designation of defined biological concept in a special language by a linguistic expression are known as biological terms. Textbook is a prime source of lessons for teachers and students. Through textbook the knowledge is transferred to next generations. So, it should be appraised according to new discoveries and needs of the nation. According to encyclopaedia of education 2008 "textbook is a printed and bound artefact for each year or course of study and contain fact and ideas around certain subjects." Due to much dependence on textbooks, it is essential that textbook should be complete in itself. So textbook should be appraised on continual basis. Textbooks tend to focus on the disciplines of science; they emphasize words and specialized terminology.

\section{Gigantic problems of secondary schools' science education in Pakistan}

Loading [MathJax]/jax/output/CommonHTML/jax.js

Page 3/20 
The rise and fall of the nations depend on the quality of human resources, which can be properly developed and deployed in the right direction only with right education. The overall position of a nation in the world community at large is generally idealized by determining the standards of its educational system. However, in Pakistan, the quality of secondary education has a declining trend. It is realized that science education in particular is reaching lowest ebb and needs to be improved urgently. At the time of independence and thereafter there remained acute shortage of teachers, laboratories were poor and ill equipped and curriculum had little relevance to present day needs (Memon, 2007). In Pakistan, much teaching (which can be described as traditional) is based on teacher-centered, lecture presentation and the students memorize the teachers' words by heart. Credit is given of the correct recall of as much as possible in formal tests and examinations. This approach does not occur in all countries and education systems but is a particular feature of much Pakistani education and in many other countries (Safdar, 2007).

Since its birth, the hottest issue in Pakistan has been standard of education; the educationalists of our country have been really worried about. The individuals of the society have their own view point regarding standard of education in Pakistan. The efforts of every government in Pakistan to raise the educational standards have been limited only to prepare educational policies in papers. No practical implementation of recommendations presented in any educational policy to rise educational standard has ever been found. Until now the role of secondary and college education in Pakistan has been simply preparation for tertiary education, which in the minds of most people means strictly a university education. Pakistan's educational documents are not acceptable abroad due to our poor educational standards. The claims of government of Pakistan regarding literacy rate of $47 \%$ is totally wrong. The actual figures of literacy rate are at about $20 \%$ at secondary level according to independent analysts and educational organizations (Kazmi, 2016).

There are dreary and uninteresting textbooks written for Pakistani textbook boards and schools, and they just overwhelm students with information. Teachers, and thus uninspiring, are either untrained or poorly educated. In teaching approaches that evoke logic and curiosity, teaching science requires extra care and special preparation by teachers (Nayyar, 2016). Unfortunately, in the vast majority of Pakistan's colleges, public or private, none of this is obvious, except in some costly elite schools. English is an international language and belongs to native speakers as much as it belongs to native English speakers of any language in any region. Pakistan is one of those countries where English is quickly expanding (Raza, 2008). The topic of the teaching medium of science education is a dynamic one (Asif et al., 2020). Concepts and their interpretations can be better expressed and received in a language that is readily understood. The overwhelming majority of high school students are barely able to understand English. Texts written in Urdu or mother tongues should be the strongest in this regard. But with vocabulary, the issue emerges because of reading some Urdu science textbooks that maintain transcribed English terminology in Urdu.

The challenge faced by a class $V$ student reading words like 'endangered animals' or names of complex organic molecules in Urdu is not impossible to picture. Only a small fraction of the overall number of secondary school students get to study science properly, while science terminology and principles behind them will be unknown to most secondary school students today. The content relevant to biology living organisms are given in textual form to students as "textbook of biology for class IX. Terms are used to give specific concepts". Shafi (2010) stated that terminology used in the subject of biology for class X was difficult for most of the students. She recommended that relevant teachers should explain the source of the words and their meanings so that difficulty of students may be solved. Khokhar (2008) as cited by Hussain (2001) pointed out the availability of "glossary" in the textbook which was not fulfilling the requirements of the teachers as well as the students. That is why, a good glossary was recommended for curriculum development.

\section{Statement of the problem}

By improving the quality of science education at elementary and secondary schools, Pakistan will perform better in international trade and the service sector. Science and Technology subjects are taught in English in high schools, but Pakistan suffers from a lack of proficient teachers. English is not widely spoken in the classroom, except among graduates of prestigious universities, and there have been few educational resources for educators to study. Secondary school students are facing stress challenges due to the intrusion with their own words. That may be a natural Pashto tendency of the first-language or mother-tongue. Many private schools that advertise themselves as offering English medium education often lack the capacity to live up to their promises, and this shortfall is not limited to only the government sector. Not enough is being achieved on the scientific terms of Pakistan's secondary school students' pronunciation. Textbooks are the centre of all teaching and learning activities. The content of textbook provides interaction between the teacher and the students. If the content is overloaded with high profiled concepts and terms, it creates problem in understanding the text. The contents (text and informative box) and diagrams are included in textbook of science subjects for secondary schools. The difficulty in learning of science may be due to high profile terminology. This study has been designed to analyze the cacoepy of scientific terms included in Textbooks of Khyber Pakhtunkhwa Board for class IX and X.

\section{Significance of the study}

This study was an attempt to make learning of science subjects easy for the secondary level students of Pakistan. This study examines the cacoepy of science terms in secondary school students of government high school students Kaghzai, Kohat (KPK). According to Ngozi Okonjo-Iweala, managing director, World Bank, "the complexity in such cases is that an increasing number of young people in secondary education means increasingly diverse talents, diverse job interests and job opportunities but an additional complexity is the shifting needs of employers, which are changing rapidly". Current reseach includes secondary school students due to the importance of secondary education. The research is especially significant since the students in this region are from Pashtun tribes, and their pronunciation of scientific terms varies from their standard pronunciation. Since preventing mispronunciations is essential to avoiding the incorrect understanding of scientific terminologies. This thesis will help raise awareness of certain complicated scientific terms and will assist science teachers in addressing these terms and encourage students to practice further in order to achieve proper pronunciation. The finding of this research would also facilitate the textbook board in replacing complex science terminology with simple alternative words. It is hoped that the current research would be helpful worldwide as well it will open new doors for researchers to find out alternate native and easy scientific terms.

\section{Research Questions}


2. What are the views of secondary school science teachers regarding the secondary level science textbooks by Khyber Pakhtunkhwa Textbook board?

\section{Research Objectives}

1. Identifying the cacoepy of common science terminology by secondary school students

2. Analysis of the science teachers views on secondary level science textbooks produced by the Khyber Pakhtunkhwa Textbook board

\section{LITERATURE REVIEW}

According to Durrani (1999), the diversity and expansion in science and technology is over passing all boundaries of languages and countries. According to him, terminologies are always challenging to communities but majorly these challenged the Greek, Arab, Chinese and Indian communities. Even nowadays 25 terms are being added in one million terms daily (Durrani, 1999). While there are 250 disciplines that are growing in the domain of knowledge. These large numbers of technical terms are conveyed in terms of dictionaries, books and thesaurus.

\section{Role of Scientific Terminology}

Lynch, in studies reported in 1979 and 1981, has been concerned with the levels of meaning for various terminologies commonly included in science instruction (Lynch et al., 1979; Lynch, 1981). There is strong evidence that one major fact of the current crisis in science education is the considerable emphasis upon words/terms/definitions as the primary ingredient of science-at least the science that a typical student encounters and that he/she is expected to master (Yager, 1983). Nonetheless, study by Holliday (1981) on comprehension, scientific terminology/language, and textbook study do provide another dimension of issues related to the crisis in science education-that concerned with student study and learning. An exchange of opinions raised the issue of the appropriate use of scientific terminology in student conception studies and instruction from two different points of view (Pushkin, 1996; Lewis \& Linn, 1996).

According to one view (Pushkin, 1996), there exists a precise scientific terminology and its appropriate use is necessary if one wants to avoid confusion or creation of pseudo conceptions. According to the other view (Lewis \& Linn, 1996), in science textbooks, science writing, scientific discourse, and everyday experience, terminology is used in a broader, richer range of ways and there is little agreement concerning what constitutes the appropriate usage of scientific terms. In addition, as this second view suggests, terminological diversity, when contextualized in analogies and metaphors, contributes to an instructionally rich discussion (Levin \& Wagner, 2006).

As Lewis and Linn (1996) point out, what a careful reader might find in science and physics textbooks is rather a diverse spectrum of different ways in which it is possible to talk about scientific concepts and processes. Even when a high level of agreement is reached regarding scientific accuracy, the cognitive adequacy of such terminology, or should we say, the cognitive inadequacy of the terminology, could still obscure its use in learning (Slisko \& Dykstra, 1997).

The number of erroneous, misleading, and conflicting conceptualizations, either in different textbooks or within a single text, can hardly contribute to better teaching and learning, especially for young students (Slisko, 1994). As physicists, we know that our colleagues like to argue with each other about this "precise terminology", treating the meaning of this terminology as if it exists independently of all. Unfortunately, it is clear that there is not agreement over the meaning for many different terms, from classical ones-temperature (Baierlein, 1990) and energy (Schmid, 1982; Warren, 1982, 1983; Kemp, 1984; Mclldowie, 1995), to modern ones-relativistic mass (Bickerstaff \& Patsakos, 1995). Because physicists have such a propensity for not agreeing on the meaning of the terms (precise though their individual definitions may be), even if such a collection of precisely defined terms were generated by someone, it seems that we are still guaranteed confusion. So a problem that appears with Pushkin's argument is that precision alone is not sufficient. Agreement is also necessary for this imagined avoidance of confusion, but we do not think there is the implied agreement in the physics community.

Teaching can be thought of as an effort to help students examine their "initial knowledge," colored with many alternative conceptions, as well as to build "new knowledge" consistent with their new experiences with natural phenomena. Much research has paid attention to the study of student initial knowledge (Pfundt \& Duit, 1994), but we are still a long way from being as effective as we wish at enabling students to actually reconstruct their initial knowledge.

Arguing against the term heat energy, Pushkin (1996) says that the right term is heat, or in more elaborated form "thermal energy flow" or "transfer of thermal energy due to a temperature differential between substances." Accordingly, "heat energy" should be changed to "heat" because heat is a process (flow, transfer). Contrary to this view, Lewis and Linn (1996) argue that they use the term "heat energy" in order to reinforce the idea that heat is a "form of energy" and that such a use supports a process rather than a substance model of thermal phenomena.

\section{Scientific Concepts}

Many things are present around us which we can observe and see. Our mind has ability to perceive the object and can create conceptual image. This conceptual image helps to recreate the object even when it is not in the reach of our senses. Students build their concepts about the world by studying science and use these concepts to interpret the world. According to Akhtar (2000), biological concepts are built by sensation of things around the learner, perception of ideas and conception in mind. Washton (1967) stated that concepts are built by actual experience of pupils. Chauhan (1987) described that concepts are build by following the principles of simple to complex, analysis to synthesis, from induction to deduction and from particular to generalization. Concepts are mental perception and we use certain carriers to describe our concepts in languages. These carriers of language (word) have specific meanings and are in common use as they become technical terms.

\section{Scientific terminology}

Scientific terminology is the part of the language that is used by scientists in the context of their professional activities. While studying nature, scientists often encounter or create new material or immaterial objects and concepts and are compelled to name them. Many of those names are known only to professionals (Wikinedia)

Loading [MathJax]/jax/output/CommonHTML/jax.js 


\section{Term}

A term is defined as the designation of defined concept in a special language by a linguistic expression. Term can also be defined as, "a word or phrase used to describe a thing or to express a concept, especially in a particular kind of language or branch of study" (OxfordLanguages).

\section{Terminology}

The study of terms is called terminology. It is defined as According to Din (1986); "The total concepts and their designations in a specific domain is called terminology" (p.7). Terminology is helpful for the learner in every specific subject, as described by (Condamines, 1993) the level of competence of the text users on the subject presented increases in accordance with the amount of terminologies used.

\section{Types of Terms}

According to online dictionary, there are three dimension signed with the word term. a. Linguistics means the formal (symbolic representation) aspect of term. b. Cognitive means the conceptual representation of term. c. Ontological, the referent, the object form of reality to be named. Characteristics of Terms Rodilla (1998) Describe that there are three main characteristics of term these are as follows:

\section{Precision}

Precision means delimited, and a monosemic and related to a concept. According to Wright and Buddin (2001), a term will be précise when: 1. Its meaning must be defined in advance (in dictionary or thesaurus related to a particular discipline). 2 . This means there is a monosemic word which means having single meaning, and should not be synonymous.

\section{Emotional Neutrality}

Terms will be affective when these are free of personal or subjective components, and belong to the standard record. Edit the words and the information relevant to specific discipline, so that conceptual influence of the content became clear. Emotional categorically rejected interference in certain areas. Scientific terminology is used when a number of conditions in certain areas with the emotional neutrality disappears and intersect the common language. A term is emotionally neutral when it is affective, have subjective component and are standardized.

\section{Stability}

Stability is a measure of fitness and stability can attain when the term is valid with its concept and referent associated over time. Scientific and Technological Terms According to American Heritage Science Dictionary (2016), in science the scientific terms are used to represent the mind processing perception, understanding and communication. In nature when scientists encounter new material object or concept, they compelled to give them authorized name that become the scientific term understandable by scientist worldwide.

\section{Difficult /Easy Terms}

Specific terms are given to the students and they have pointed out many terms as difficult. For examples quiescence, triglyceride, aortic semilunar valve and many others from textbook. They have also pointed out some terms as easy to learn. For example, a biotic, ascent of sap, bolus and many others.

\section{Simple /Complex Terms}

According to online dictionary of grammar, a term is simple when it is made of a single morpheme e.g. "aqueous". A term is complex when it is made of two or more morphemes. Complex terms consist of a base or root and one or more affixes e.g. inhibitor is complex term is also formed by the combination of two roots. According to Durrani (1999) where ever terms are used it is important to give their source that should be reliable and according to international standards (ISO 690). Source should be given with full title, abbreviated title or codes. Abbreviated titles are user friendly, when they are given in frequently used source (dictionary or thesaurus). In Pakistan the primary sources for student learning in most of the areas is text book. Text book contains many abbreviated terms. For examples NACP, NAD, NADP, NADPH. These terms are not properly explained in textbook. The terms when analyzed by researcher it was found that their origins were missing

\section{Teaching of Scientific Terms}

Scientific terms are of two types while teaching.

1. 1. The terms which are represent able with the help of diagram e.g., urinary system.

2. 2. The terms which cannot be represented by the help of figures, pictures, graphs, illustrations map/movies. e.g., denaturation of enzyme.

\section{Terminology in science textbooks}

Terminology is a central feature in most science textbooks. Since most science classes utilize textbooks as the primary determiners of what students do and what they must learn, it is apparent that science words and terms are a major focus in secondary schools' science (Mastropieri, 2003). The literature concerning needed vocabulary and rate of vocabulary mastery in learning a foreign language is not clear. After great concern for vocabulary and grammar in the past, many modern foreign language experts tend to downplay the importance of vocabulary per se. Nonetheless, Pillet (1974) recently has called for the standardization of beginning vocabulary. Valette and Valette (1975), popular authors of textbooks in French, include 1750 words in their text for high school use; their college text includes 3000 words.

In an early work, Coleman (1934, p. 241) suggests that vocabulary words should be limited to no more than 2000 for each of the first two years of studying

Loading [MathJax]/jax/output/CommonHTML/jax.js ) has reported that the first two years of high school study of French should be limited to 1475 words; she

Page 6/20 
indicated that college students with four years of high school preparation could master 3500 new words per year. Grittner (1977) in other work suggests that 1000 to 2000 new "items" be a maximum beginning level for study, that vocabulary included but 1200 words for levels 1 and 2 , and that ths can be increased to 2000 for intermediate students.

There is general agreement among foreign language researchers concerning vocabulary. It seems that the 1250 words that Hurd, Robinson, McConnell, \& Ross used for middle/junior high school study of a foreign language is generally accepted. Further, the 2500 words per year for high school (and 3000 to 3500 for college) reported by Hurd and Brandwein is supported by the foreign language scholars who have written on the subject.

A review of research concerning vocabulary development is of value in connection with science vocabulary and the focus upon vocabulary in science teaching, K-12. Dale (1962) has done extensive research and he has reviewed the status of past research as well. He offers a caution to persons involved with reading that is appropriate for persons involved with science teaching. He generalizes that excessive emphasis on words apart from their meaning results in memorizing subject matter with mere verbalisms. He urges teachers to emphasize meanings, not words. The NSF reports suggest the need for this information for science teachers; in addition, there is much to suggest the need for their heeding the advice based upon reading/vocabulary research.

With such an extreme focus on terminology, science requires a disproportionate percent of time for vocabulary mastery. In almost every case more attention to vocabulary is necessary in typical science classrooms than is necessary for mastering a foreign language. Newer science programs emphasize terms to a lesser extent but they are far less popular among teachers as choices for textbooks. More studies are needed concerning grade level and course articulartion as well as "needed" vocabulary development in science. Information is needed concerning terminology as related to teacher questioning and evaluation (Chiappetta, 1991).

\section{Factors associated with the cacoepy of scientific terms}

The fact that some students are able to acquire a reasonable knowledge of Science in few months and the others are not able to reach the same level within some few years depends upon various factors. As noted by Shoebottom (2012), some of these factors can affect acquiring pronunciation skills prosperously (e.g. determination and hard work in training pronunciation skills), some of these factors are far beyond human control. Generally, these factors can be distinguished into two main groups, internal and external (Mikuláštíková, 2012).

\section{Internal Factors}

These are the factors which are incorporated into student's individual language.

- Age: It is proved that children are the most talented ones in terms of acquiring English as a Foreign Language. However, adults can achieve a reasonable progress in obtaining pronunciation skills successfully if they are well motivated and determined.

- Personality. Students who are of introvert character are usually afraid of expressing themselves orally; they do not rather look for any opportunities to speak. On the other hand, students who are of extrovert character are usually seeking for taking part in every conversation possible, ignoring their mistakes.

- Motivation: It is important to distinguish between intrinsic and extrinsic motivation. Students who are intrinsically motivated exhibit greater interest and enjoyment in their science education. Students who need to study science in order to take a better job or to communicate with relatives who live in an English speaking country (so they are extrinsically motivated) are also likely to achieve better results.

- Experiences: Students who have already been exposed to some foreign language have greater chances to acquire a new language easier than students who have never encountered one.

- Cognition: It is believed by some linguists that the cognitive abilities that are stronger with some students than with some others can lead to faster language progress.

- Native language: Students who try to acquire a foreign language which belongs to the same language family as their native language have greater chance than those students who try to master a language from a family group that is different from their native tongue (Shoebottom, 2012).

\section{External Factors}

These factors characterize the particular language learning situation.

- Curriculum: There has been little or no attention to the development of a science curriculum. There is a mismatch between the science curriculum found in schools and that which $90 \%$ of the students want and need (Yager, 1983).

- - Instruction: It depends on teacher's teaching skills and abilities how successful students are in terms of their science learning. In addition to this, students who are exposed to some English Language Teaching also in other subjects reach greater progress.

- Culture and Status: It has been noticed that students whose culture possesses a lower status are mostly slow learner in science subjects.

- Motivation: It is proved that students who are continually supported to better their language skills by their families or teachers reach a greater success.

- Access to native speakers: Students who have the possibility to meet with native speakers lose the fears to communicate. Native speakers provide a linguistic model and an appropriate feedback for students (Shoebottom, 2012; Mikuláštíková, 2012).

\section{Research Methodology Study design}


This study was conducted to analyse the scientific terms used in science textbooks for secondary level students. It is a field study of exploratory and mixed approaches (using both quantitative and qualitative methods of data collection) in which cacoepy of scientific terminology were proposed. On the basis of observations, interviews and oral events, these words were compiled. Necessary words were transcribed and presented after selection. The thesis is exploratory in nature, because no substantial study on the same subject may be contained in the literature.

\section{Study population and sampling}

This research study includes 112 students from Government Secondary School Kaghzai, district Kohat. From the subjects of biology, chemistry and physics, scientific terminology were used.

Table 1

The distribution of the participants

\begin{tabular}{|ll|}
\hline Grade/Class & Number of students \\
\hline 9th A & 25 \\
\hline 9th B & 26 \\
\hline 10th A & 33 \\
\hline 10th B & 28 \\
\hline Total strength & 112 \\
\hline
\end{tabular}

\section{Data collection methods and instruments}

Mixed method research approach was used for data collection. Primary data was collected on basis of observation, interviews and oral activities. Secondary data was obtained by transcribing and arrangement of primary data. The data collected through the following procedures.

- The interview and discussion with the secondary school science teachers.

- The researcher asked the students to read the text having important terminologies and definitions.

- One by one of the students read the text, while the researcher recorded their voices and observed the difficulties made by them.

- The researcher assigned the tasks of learning and understanding the concept of some terminologies from each chapter.

- One by one of the student presented his view about the assigned terminologies and the researcher noted the remarks on page.

- Then, the researcher analyzed the data collected.

\section{Data analysis methods}

Data processing was performed with the help of the percentage frequency method using Microsoft Excel. The researcher used certain criterion based on Best's (1981) criterion in order to know how well the students pronounce the scientific terminologies and how well they understand its concepts.

Table 2

Best's criteria for data analysis

\begin{tabular}{|ll|}
\hline Categories & Number of mistake in percentage \\
\hline Excellent & $0-25 \%$ \\
\hline Good & $26-50 \%$ \\
Fair & $51-75 \%$ \\
\hline Poor & $76-100 \%$ \\
\hline
\end{tabular}

\section{Position of Researcher}

The researcher acted as planner, performer, and collector of data and to report the results of research. The planner is the researcher processing, to find out and set the result of data. The performer is the result of the collections will be analyzing and explaining of the data by making conclusion. The collector is the researcher determined the subject of research and providing the instruments of data collection. So, the researcher's presence is very important and needed.

\section{Limitations of the study}

Owing to the lack of time, the present study is limited to the Government High School Kaghzai Kohat students (boys) in grades 9 and 10.

\section{Ethical considerations}

Research approval was obtained from the Principal of institution before the commencement of data collection.

\section{Results}

As the researcher explained at the previous chapter, this research used the observations, interviews and oral events like presentation. The observations, interviews and oral events were used to find out the cacoepistic scientific terms difficult to be pronounced and learned or understand their concepts by the Loading [MathJax]/jax/output/CommonHTML/jax.js Kohat. These methods also helped in finding out the factors associated with the difficulty of students. 
A total of 259 cacoepistic scientific words/terms which were difficult to be pronounced and learned or understand their concepts by the secondary school students were listed according the classes and subjects in Table 3. Results revealed that majority of the difficult terms were found in Biology followed by Physics and then Chemistry. Moreover, the results also showed that students of class IX reported more difficult terminologies as compared to class X. Findings of the current research are following 
Table 3

List of cacoepistic scientific terms from secondary schools/class IX and X Biology, Chemistry and Physics books.

\begin{tabular}{|c|c|c|c|c|c|}
\hline Biology 9th & Biology 10th & Chemistry 9th & Chemistry 10th & Physics 9th & Physics 10th \\
\hline Algae & Abdominal cavity & Absolute zero & Anthropogenic & Analogue & Altitude \\
\hline Alveoli & $\begin{array}{l}\text { Acquired immunodeficiency } \\
\text { syndrome }\end{array}$ & Acetylene & Baeyer's test & Archeology & Amplitude \\
\hline Amino acid & Adenosine Triphosphate & Actinides & Bessemerization & Archimedes & Aperture \\
\hline Anthophyta & Adhesion & Aliphatic hydrocarbons & Carboxylation & Artificial & Architectural \\
\hline Aorta & Adolescence & Amphiprotic & Characteristics & Australopithecus & Assignment \\
\hline Apoptosis & Allele & Arrhenius & Dehydrohalogenation & Cartesian & Characteristics \\
\hline $\begin{array}{l}\text { Binomial } \\
\text { Nomenclature }\end{array}$ & Amoeba & Aufbau principle & Denaturing & Celestial & Chirping \\
\hline Brassica compestris & Anabolism & Avogadro's number & Dissociation & Centrifuge & Cochlea \\
\hline Bronchioles & Anaerobic & Burette & Elimination reaction & Coefficient & Curvature \\
\hline Carbohydrates & Androecium & Carboxylic & Gaseous state & Conventionally & Eclipse \\
\hline Carolus Linnaeus & Angiosperm & Chlorofluorocarbon & Granulation & Doubtful & Edges \\
\hline Chlamydomonas & Apical meristem & Coefficient & Inflammability & Fahrenheit & Features \\
\hline Chyme & Atherosclerosis & Colligative property & Manufacture & Gradually & Gradually \\
\hline Collenchyma & Bronchioles & Compressibility & Metallurgical & Inertia & Incandescent \\
\hline Cutaneous & Calvin cycle & $\begin{array}{l}\text { Electromagnetic } \\
\text { spectrum }\end{array}$ & Oligosaccharides & Initially & Longitudinal \\
\hline Cytokinesis & Cervical & Electronegativity & $\begin{array}{l}\text { Potassium } \\
\text { permanganate }\end{array}$ & Knob & Machined \\
\hline Diaphragm & Chemoautotroph & Instantaneous & Precipitate & Knowledge & Magnitude \\
\hline Diphtheria & Chloroplast & Lanthanides & Quantitative & Maneuvered & Mechanical \\
\hline Duodenum & Commensalism & Locant & Sedimentation & Measurement & Molluscs \\
\hline $\begin{array}{l}\text { Endoplasmic } \\
\text { reticulum }\end{array}$ & Deciduous & Molybdenum & Stomach & Mechanisms & Negligible \\
\hline Fungi & Dendrite & Neutralization & Structural formula & Meniscus & Neighboring \\
\hline Heterogeneous & Deoxyribonucleic acid & Polymerization & & Metallurgical & Nuisance \\
\hline Interstitial & Diastole & Precipitation & & Negligible & Pitch \\
\hline Lymphatic & Electrophoresis & Pungent & & Peculiar & Schematic \\
\hline Marasmus & Epididymis & Quantization & & Phenomena & Seismic \\
\hline Meiosis & Exocytosis & Stoichiometry & & Precautions & Sinusoidal \\
\hline Meristematic & Gametogenesis & Substituent & & Precisely & Stretched \\
\hline Mitochondria & Glycogenesis & & & $\begin{array}{l}\text { Proxima } \\
\text { centurial }\end{array}$ & Tangential \\
\hline Mitoses & Gynoecium & & & Psychological & Trough \\
\hline Morphology & Homeostasis & & & Sketch & Wiggle \\
\hline Necrosis & $\begin{array}{l}\text { Human immunodeficiency } \\
\text { syndrome }\end{array}$ & & & Sledge hammer & \\
\hline Paleontology & Interstitial fluid & & & Substituting & \\
\hline Paramecium & Krebs cycle & & & Tangentially & \\
\hline Peristalsis & Neurotransmitter & & & Torricellian & \\
\hline Phagocytosis & Nicotinamide Adenine Dinucleotide & & & Unfortunately & \\
\hline Physiology & Osteoporosis & & & Unfortunately & \\
\hline Pinocytosis & Parasympathetic & & & Unnoticeably & \\
\hline Prokarvotes & $\begin{array}{l}\text { Parenchvma } \\
\text { CommonHTML/iax is }\end{array}$ & & & Visualization & \\
\hline
\end{tabular}

Page $10 / 20$ 


\begin{tabular}{|c|c|c|c|c|c|}
\hline Biology 9th & Biology 10th & Chemistry 9th & Chemistry 10th & Physics 9th & Physics 10th \\
\hline Pyloric sphincter & Pasteurization & & & Whirled & \\
\hline Respiration & Pituitary & & & Whistles & \\
\hline Salientia & Pneumonia & & & & \\
\hline Saprotrophic & Pseudo coelomate & & & & \\
\hline Sclerenchyma & Pyrimidine & & & & \\
\hline Sinuses & Pyruvate & & & & \\
\hline Taxonomy & Rhesus & & & & \\
\hline Taxonomy & Sebaceous & & & & \\
\hline Theophrastus & Segregation & & & & \\
\hline Turgor & Seminiferous & & & & \\
\hline Vasodilation & Testosterone & & & & \\
\hline Visalius & Thoracic & & & & \\
\hline Xylem & Urinogenital & & & & \\
\hline
\end{tabular}

Table 4 shows analysis of biological scientific terms. The researcher found only few terms were placed in Excellent category as they were correctly pronounced and learned by more than $75 \%$ students. Terminologies in poor and fair category should be replaced by easy word or their Urdu should be incorporated with these terms; that will help in easy learning of biology for students of secondary schools.

The terminologies listed in Table 4 also reflect that biological terms were belonging to two major domains, botany related to plants and zoology related to animals. The Text was not equally divided and majority of biological terms were from zoology. Authors should give equality in building concept of Biology by giving equal information related to plants and animals. 
Table 4

Analysis of Biology cacoepistic terms on the basis of students' interpretation regarding difficulty in pronunciation, spellings and concept

\begin{tabular}{|c|c|c|c|}
\hline Biology 9th & Category & Biology 10th & Category \\
\hline Algae & Good & Abdominal cavity & Excellent \\
\hline Alveoli & Good & Acquired immunodeficiency syndrome & Poor \\
\hline Amino acid & Excellent & Adenosine Triphosphate & Poor \\
\hline Anthophyta & Poor & Adhesion & Fair \\
\hline Aorta & Excellent & Adolescence & Fair \\
\hline Apoptosis & Good & Allele & Good \\
\hline Binomial Nomenclature & Fair & Amoeba & Good \\
\hline Brassica compestris & Poor & Anabolism & Good \\
\hline Bronchioles & Good & Anaerobic & Good \\
\hline Carbohydrates & Good & Androecium & Fair \\
\hline Carolus Linnaeus & Poor & Angiosperm & Fair \\
\hline Chlamydomonas & Poor & Apical meristem & Fair \\
\hline Chyme & Fair & Atherosclerosis & Poor \\
\hline Collenchyma & Poor & Bronchioles & Good \\
\hline Cutaneous & Good & Calvin cycle & Fair \\
\hline Cytokinesis & Good & Cervical & Poor \\
\hline Diaphragm & Good & Chemoautotroph & Fair \\
\hline Diphtheria & Fair & Chloroplast & Excellent \\
\hline Duodenum & Poor & Commensalism & Fair \\
\hline Endoplasmic reticulum & Good & Deciduous & Fair \\
\hline Fungi & Good & Dendrite & Good \\
\hline Heterogeneous & Good & Deoxyribonucleic acid & Poor \\
\hline Interstitial & Fair & Diastole & Fair \\
\hline Lymphatic & Excellent & Electrophoresis & Poor \\
\hline Marasmus & Good & Epididymis & Poor \\
\hline Meiosis & Good & Exocytosis & Fair \\
\hline Meristematic & Poor & Gametogenesis & Poor \\
\hline Mitochondria & Fair & Glycogenesis & Fair \\
\hline Mitoses & Excellent & Gynoecium & Fair \\
\hline Morphology & Excellent & Homeostasis & Good \\
\hline Necrosis & Good & Human immunodeficiency syndrome & Poor \\
\hline Paleontology & Poor & Interstitial fluid & Poor \\
\hline Paramecium & Fair & Krebs cycle & Fair \\
\hline Peristalsis & Good & Neurotransmitter & Good \\
\hline Phagocytosis & Good & Nicotinamide Adenine Dinucleotide & Poor \\
\hline Physiology & Fair & Osteoporosis & Good \\
\hline Pinocytosis & Fair & Parasympathetic & Poor \\
\hline Prokaryotes & Good & Parenchyma & Fair \\
\hline Pyloric sphincter & Poor & Pasteurization & Fair \\
\hline Respiration & Fair & Pituitary & Poor \\
\hline $\begin{array}{l}\text { Colinnt } \\
\text { HTML/iax is }\end{array}$ & Good & Pneumonia & Fair \\
\hline
\end{tabular}




\begin{tabular}{|llll|}
\hline Biology 9th & Category & Biology 10th & Category \\
\hline Saprotrophic & Good & Pseudo coelomate & Poor \\
\hline Sclerenchyma & Poor & Pyrimidine & Fair \\
\hline Sinuses & Fair & Pyruvate & Good \\
\hline Taxonomy & Fair & Rhesus & Fair \\
\hline Theophrastus & Poor & Sebaceous & Good \\
\hline Turgor & Fair & Segregation & Good \\
\hline Vasodilation & Fair & Seminiferous & Poor \\
\hline Visalius & Poor & Testosterone & Poor \\
\hline Xylem & Good & Thoracic & Good \\
\hline & & Urinogenital & Fair \\
\hline
\end{tabular}

Analysis of Table 5 and 6 revealed that most of the terms were found difficult hence, fall in the category of fair and poor. The reason is that scientific terminologies, listed in Table 4, 5 and 6, were derived from many languages such as Greek, Latin, Arabic origin. These languages are ancient and are not native to Pakistani secondary school students. So these terms should be replaced by alternative and easy native language terms or their meaning and origins must be clearly described in textbooks of Khyber Pakhtunkhwa textbook board. If authors attempts to described their meaning and origin, it will enhance learning of biology, chemistry and physics, and will make it easy for secondary level students to avoid cacoepy, to understand and building better concepts. 
Table 5

Analysis of Chemistry cacoepistic terms on the basis of students' interpretation regarding difficulty in pronunciation, spellings and concept

\begin{tabular}{|c|c|c|c|}
\hline Chemistry 9th & Category & Chemistry 10th & Category \\
\hline Absolute zero & Fair & Anthropogenic & Poor \\
\hline Acetylene & Good & Baeyer's test & Fair \\
\hline Actinides & Fair & Bessemerization & Poor \\
\hline Aliphatic hydrocarbons & Poor & Carboxylation & Fair \\
\hline Amphiprotic & Poor & Characteristics & Good \\
\hline Arrhenius & Poor & Dehydrohalogenation & Poor \\
\hline Aufbau principle & Poor & Denaturing & Excellent \\
\hline Avogadro's number & Poor & Dissociation & Fair \\
\hline Burette & Fair & Elimination reaction & Good \\
\hline Carboxylic & Excellent & Gaseous state & Excellent \\
\hline Chlorofluorocarbon & Good & Granulation & Fair \\
\hline coefficient & Fair & Inflammability & Fair \\
\hline Colligative property & Fair & Manufacture & Good \\
\hline Compressibility & Poor & Metallurgical & Fair \\
\hline Electromagnetic spectrum & Poor & Oligosaccharides & Poor \\
\hline Electronegativity & Fair & Potassium permanganate & Poor \\
\hline Instantaneous & Fair & Precipitate & Good \\
\hline Lanthanides & Good & Quantitative & Fair \\
\hline Locant & Good & Sedimentation & Fair \\
\hline Molybdenum & Fair & Stomach & Fair \\
\hline Neutralization & Excellent & Structural formula & Good \\
\hline Polymerization & Good & & \\
\hline Precipitation & Fair & & \\
\hline Pungent & Poor & & \\
\hline Quantization & Fair & & \\
\hline Stoichiometry & Poor & & \\
\hline Substituent & Fair & & \\
\hline
\end{tabular}


Table 6

Analysis of Physics cacoepistic terms on the basis of students' interpretation regarding difficulty in pronunciation, spellings and

\begin{tabular}{|c|c|c|c|}
\hline Physics 9th & Category & Physics 10th & Category \\
\hline Analogue & Good & Altitude & Fair \\
\hline Archeology & Good & Amplitude & Fair \\
\hline Archimedes & Poor & Aperture & Poor \\
\hline Artificial & Fair & Architectural & Poor \\
\hline Australopithecus & Poor & Assignment & Good \\
\hline Cartesian & Poor & Characteristics & Good \\
\hline Celestial & Fair & Chirping & Fair \\
\hline Centrifuge & Fair & Cochlea & Poor \\
\hline Coefficient & Fair & Curvature & Fair \\
\hline Conventionally & Poor & Eclipse & Fair \\
\hline Doubtful & Good & Edges & Good \\
\hline Fahrenheit & Fair & Features & Good \\
\hline Gradually & Fair & Gradually & Good \\
\hline Inertia & Good & Incandescent & Poor \\
\hline Initially & Good & Longitudinal & Good \\
\hline Knob & Good & Machined & Good \\
\hline Knowledge & Excellent & Magnitude & Good \\
\hline Maneuvered & Poor & Mechanical & Good \\
\hline Measurement & Good & Molluscs & Fair \\
\hline Mechanisms & Good & Negligible & Fair \\
\hline Meniscus & Fair & Neighboring & Fair \\
\hline Metallurgical & Fair & Nuisance & Poor \\
\hline Negligible & Fair & Pitch & Good \\
\hline Peculiar & Fair & Schematic & Good \\
\hline Phenomena & Good & Seismic & Poor \\
\hline Precautions & Good & Sinusoidal & Poor \\
\hline Precisely & Fair & Stretched & Fair \\
\hline Proxima centurial & Poor & Tangential & Poor \\
\hline Psychological & Good & Trough & Fair \\
\hline Sketch & Excellent & Wiggle & Fair \\
\hline Sledge hammer & Poor & & \\
\hline Substituting & Poor & & \\
\hline Tangentially & Poor & & \\
\hline Torricellian & Poor & & \\
\hline Unfortunately & Fair & & \\
\hline Visualization & Good & & \\
\hline Whirled & Fair & & \\
\hline Whistles & Fair & & \\
\hline
\end{tabular}

\section{Interview and discussion with students}


It is pertinent to ask what the role of attitudinal research might be in a country with a weak infrastructure like Pakistan, which has a national goal of achieving an effective State science education system (GOP, 2001). Bloom (1976) has attributed as much as $25 \%$ of the variation in achievement in school to attitude. As it can be argued that attitudes have a fundamental impact on later behaviour (Ajzen, 1988), it follows that success in school science and hence achieving the national goals requires classroom actions from the teacher that inculcate positive attitudes (lqbal et al., 2008).

Randomly selected 10 students from each class $(n=40)$ were interviewed by the researcher regarding their science textbooks. To make the children more comfortable, they were interviewed in their as a whole, although it is acknowledged that with these young children the responses of one more articulate child might lead the others. They were excited at being given the chance to participate. Questions were put and answered in 'Pashto', the local language of Kaghzai, Kohat.

Table 7 and figure 1 shows that almost all students like science subjects ( $n=35 / 40)$ which shows their motivation to science despite limited resource provision in the schools. Majority of students mentioned the difficulty of textbook contents and terms. The students also discussed that through removal of unnecessary area and inserting real life examples and activity, it is easier to learn and understand science topics. All the students agree with the insertion of meaning and pronunciation style of specific/important terms in Urdu at the start page of each chapter will facilitate them more as an initiative is taken by the Provincial Institute of Teacher Education, Peshawar (KPK) for Continuing Professional Development (CPD) Programme for Primary School Teachers (Table 8).

Table 7

Responses of 40 students chosen at random to the interview questions/statements

\begin{tabular}{|c|c|c|}
\hline \multirow[t]{2}{*}{ Questions/Statements } & \multicolumn{2}{|c|}{ Responses $(n=40)$} \\
\hline & Yes & No \\
\hline Do you like science subjects? & 35 & 5 \\
\hline I should like to be a scientist & 11 & 29 \\
\hline Science makes me think & 32 & 8 \\
\hline Is it easier for you to understand science? & 11 & 29 \\
\hline Science is good for everybody & 37 & 3 \\
\hline Science is just too difficult & 22 & 18 \\
\hline Science terminology in your textbook is difficult & 29 & 11 \\
\hline Is it difficult for you to understand science because of terminologies? & 16 & 24 \\
\hline Insert the meaning and pronunciation of specific/important terms in Urdu at the start page of each chapter. & 40 & 0 \\
\hline
\end{tabular}

Table 8. Keyword to inform participants about the following vocabulary/ concepts/ terms during the session, so that, they will understand meaning with correct pronunciation (Source: CONTINUING PROFESSIONAL DEVELOPMENT (CPD) PROGRAMME FOR PRIMARY SCHOOL TEACHERS, ACADEMIC YEAR 2020-21)

\begin{tabular}{|c|c|c|c|}
\hline Vertebrates & Invertebrates & Characteristics & Mammals \\
\hline 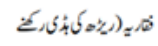 & 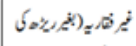 & تواس & ياليا \\
\hline المابزر) & 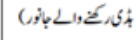 & & \\
\hline Reptile & Fish & Birds & Amphibians \\
\hline 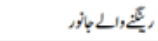 & يلي & $-x_{4}$ & 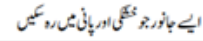 \\
\hline Monocotyledonous & Dicotyledonous & Seeds & Veins \\
\hline يمحنالإياי- & קוקוالו"י & $\varepsilon$ & 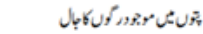 \\
\hline
\end{tabular}

\section{Interview and discussion with science teachers}

Table 8. Summary of teachers' interview/discussion responses 


\begin{tabular}{|c|c|c|c|}
\hline S.No & Statement & Agree & Disagree \\
\hline 1. & Lack of students interest & 2 & 2 \\
\hline 2 . & Mother tongue interference & 2 & 2 \\
\hline 3. & Academic background of student matters & 4 & 0 \\
\hline 4. & $\begin{array}{l}\text { Some students are able to acquire a reasonable knowledge of Science in few months while the others are not able to reach the same level } \\
\text { within some few years. }\end{array}$ & 4 & 0 \\
\hline 5. & Science terminology in textbook is difficult & 3 & 1 \\
\hline 6. & Is it difficult to understand science because of terminologies? & 2 & 2 \\
\hline 7. & There is a mismatch between the science curriculum found in schools and that which $90 \%$ of the students want and need & 4 & 0 \\
\hline 8. & It depends on teacher's teaching skills and abilities how successful students are in terms of their science learning & 4 & 0 \\
\hline 9. & Continuous support and motivation by families or teachers could results in a greater success & 4 & 0 \\
\hline
\end{tabular}

Four secondary school science teachers from GHS Kaghzai Kohat were selected for an interview, and observed their point of view regarding secondary school textbooks evaluation in the context of students' perception, highlighted in the table 10 . Firstly, $50 \%$ teachers agree regarding the lack of students' interest and mother influence. Secondly, all teachers were agree that academic background of student matters because some students are able to acquire a reasonable knowledge of Science in few months while the others are not able to reach the same level within some few years. Majority of the teachers ( $n=3$ ) agreed upon the difficulty of science terminologies in the secondary school science textbooks while half of them acclaimed that understanding science is difficult due to difficult terminologies. All teachers were of the view that difference exists between students' needs and curriculum in the school. Likewise, it was declared that teaching skills had a greatest role in terms of science learning. According to all the teachers understanding, continuous support and motivation by families or teachers plays overriding role in students' performance and success.

Furthermore, the teachers explored that current students' failure in terms of scientific understanding shrouds in many aspects. Terminologies, for example, used in secondary text books need be explained in a simple way for the sake of better understanding for even lower-ranked student. In the same manner, it was emphasized that Science related topics, such as respiratory system, alveoli, gravitational force, projectile motion, electricity and magnetism, acid and base reactions, etc. ought to be learnt with real time activities in School.

As per the exigence of the situation, most part of the academic calendar has wasted due to intermittent disruption of educational institutions and Existing smart syllabus for COVID-19 pandemic in this context is favorable for students to prepare for exam in a limited time, but in long term, the said syllabus is futile on account that it misses major topics, like some important diseases, that are useful for students in foreseeable future.

Textbooks should be revised for language of explanation according to the level of Khyber Pakhtunkhwa secondary schools' students and some old topics should be replaced by new topics according to the need of $21^{\text {st }}$ century. Last but not the least, English has a prestigious role, aside the mother tongue, in students' building owing to its present and future as it is an international language. So, Students must be familiar with English language in schools.

\section{Discussion}

Several recent reports concerning the status of science education in secondary schools have emphasized the centrality of textbooks to instruction. Some initial investigations of the nature of textbooks have suggested that typically more new words and terms are introduced than one would expect to find in a similar time frame as foreign languages are studied. the number of new words in science often approaches the total number that could be expected in terms of total vocabulary increase at a given grade level for a given student Yager (et al., 1983). There is strong evidence that one major fact of the current crisis in science education is the considerable emphasis upon words/terms/definitions as the primary ingredient of science-at least the science that a typical student encounters and that he/she is expected to master. Therefore, this research is an approach to highlight the cacoepistic science terms on the basis of students' interpretation regarding difficulty in pronunciation, spellings and concept, to enhance science learning in secondary schools.

Textbook play an important role in secondary schools' science education. Other significant findings from the years of assessment are concerned specifically with the great dependence of teachers and textbook authors upon specialized terminology concerning the content of science. Hurd et al. (1981) in their study of the status of science in the middle/junior high school were among the first to establish the extent of the dependence upon words in traditional science teaching at that level; after examining several textbooks in common use in science classrooms in grades 6 through 9 , the investigators reported that the typical course includes 2500 new and unfamiliar words. In present study, the research listed 259 scientific words/terms which were difficult for the secondary school students to pronounce correctly and learned or understand their concepts.

Kauser and Shah (2019) found more than 100 terminolpgies in secondary school biology textbook produced by the Punjab Textbook board. As it is analyzed that majority of the difficult terms were found in Biology followed by Physics and then Chemistry. Students strength was high in Computer Science section as Loading [MathJax]/jax/output/CommonHTML/jax.js iews about terms, majority of scientific terms were difficult for different students and mostly students prefer to opt

Page $17 / 20$ 
computer science due to the difficult terms in Biology while only few opt Computer on their interest. Difficult scientific terms when analyzed were belonged to ancient languages. Moreover, the results also showed that students of class IX reported more difficult terminologies as compared to class $\mathrm{X}$. The reason may be that students of grade $\mathrm{X}$ were familiar with these terms as they have already studied the subjects in grade IX. Nowadays these terms were taught in middle level so, it is hoped that cacoeptic science terms will be reduce in future. However, some teachers associated science learning process with student characteristics (attention and preferential thinking styles) and how they influence learning. Similar remarks were given by Cano-Garcia \& Hughes (2000); Jang et al. (2010); Eick \& Reed (2002).

The Khyber Pakhtunkhwa textbook board should provide the urdu pronunciation and definitions of the discovered terminology at the beginning of each chapter since acquiring the proper terminology and meanings would aid scientific learning for secondary school students. Textbooks should be revised for language of explanation according to the level of Khyber Pakhtunkhwa secondary schools' students and some old topics should be replaced by new topics according to the need of 21 st century. Last but not the least, English has a prestigious role, aside the mother tongue, in students' building owing to its present and future as it is an international language. So, Students must be familiar with English language in schools.

\section{Conclusions}

From the above mentioned major findings, it was concluded that majority of the students like science subjects and find the terminologies difficult in which most of the terms contain more than 7 alphabets and were considered as complex terms. Due to this complexity, students feel difficulty in learning of scientific terms. Most of science terms were derived from Greek, Latin and other ancient languages, so students cannot understand their meanings. Almost every chapter of secondary school biology, chemistry and physics is overloaded with difficult terms and students felt difficulty in preparation of these chapters in which mostly difficult terms were found in biology. Mostly science teachers emphasize goals for school science that are directed only toward preparing students for the next academic level (for further formal study of science) and finishing his course within session ignoring the students ' pronunciation of scientific terminologies.

\section{Recommendations}

1. Terms should be simple and authors have to avoid terms above 7 alphabets and difficult terms should be replaced by easy alternate terms.

2. Terms should be of native language or in those languages which are taught in Pakistan or its origin and meanings should also be written/explained in Urdu language or easy English.

3. Real life activity or examples should be associated with important topics.

4. Textbooks should be altered for language of explanation to match the level of students in secondary schools in Khyber Pakhtunkhwa, and some outdated themes should be replaced with new themes to meet the needs of the twenty-first century.

5. It is important to expose the students of secondary level to such a workload which is appropriate for their studying needs instead of annual books's revision and insertion of high workload.

6. Teachers should insert few terms into science lessons for practising daily. It is enough to devote a minute or two to some pronunciation issue so that fluency of the lesson is not interrupted a lot. Pointing out a pronunciation problem when it has just arisen in the course is a good way of introducing pronunciation into the class.

7. English plays an important part in the development of students because of its present and future as an international language. The textbook board in Khyber Pakhtunkhwa should include the urdu phonology and meaning of the found terminology at the start of the chapter.

\section{Declarations}

\section{Conflict of interest}

The authors declare that they have no conflict of interest regarding the publication of this article.

\section{References}

1. Ajzen, I. (1988). Attitudes, Personality and Behaviour. Milton Keynes, UK: Open University Press

2. Akhtar, S. A. study of development of biological concepts in the book of sciences for classes (viii-x), (M.Phil thesis). Bahaudin Zakarya University, Multan, Pakistan

3. American Heritage ${ }^{\circledR}$ Dictionary of the English Language, Fifth Edition. Copyright $\odot 2016$ by Houghton Mifflin Harcourt Publishing Company. Published by Houghton Mifflin Harcourt Publishing Company. (Accessed: 14th (Nov. 2020).

4. Anwer, M., Iqbal, H. M., \& Harrison, C. (2012). Students' attitude towards science: A case of Pakistan. Pakistan Journal of Social and Clinical Psychology, $9(2), 3-9$

5. Asif, S., Afzal, I., \& Bashir, R. (2020). An Analysis of Medium of Instruction Policies in the Education System of Pakistan with Specific Reference to English Medium Education. sjesr, 3(2), 370-382

6. Baierlein, R. (1990). The meaning of temperature. The Physics Teacher, 28(2), 94-96. Critical comments of Alonso, Munley, and lona, as well as responses of Beierlein, can be found in The Physics Teacher, 28, 441-445

7. Bickerstaff, R. P., \& Patsakos, G. (1995). Relativistic generalizations of mass. European Journal of Physics, 16, 63-66

8. Bloom, B. S. (1976). Human Characteristics and School Learning. New York: McGraw-Hill 
9. Cano-Garcia, F., \& Hughes, E. H. (2000). Learning and thinking styles: An analysis of their interrelationship and influence on academic achievement. Educational Psychology, 20(4), 413-430

10. Chauhan, S. S. (1987). Advanced educational psychology. New Delhi, India: Vikas Publishing house. New Delhi

11. Chiappetta, E. L., Fillman, D. A., \& Sethna, G. H. (1991). A method to quantify major themes of scientific literacy in science textbooks. Journal of research in science teaching, 28(8), 713-725

12. Dictionary.com. https://www.dictionary.com/browse/cacoepy (Accessed: 15th Nov, 2020)

13. Durrani, A. (1999). The Terminology Papers on the New Terms of Science and Technology. Islamabad, Pakistan: The Oriental society for knowledge. Durrani, A. (2007). Textbook Development. Islamabad. Pakistan: AIOU

14. Eick, C. J., \& Reed, C. J. (2002). What makes an inquiry-oriented science teacher? The influence of learning histories on student teacher role identity and practice. Science Education, 86(3), 401-416

15. Eubanks, D., \& Eubanks, L. T. (2000). The importance of secondary education

16. Francis, L. J., \& Greer, J. E. (1999). Attitude towards science among secondary school pupils in Northern Ireland: Relationship with sex, age, and religion. Research in Science and Technological Education, 17(1), 67-74

17. Iqbal, H. M., Nageen, T., \& Pell, A. W. (2008). Attitudes to school science held by primary children in Pakistan. Evaluation \& Research in Education, 21(4), 269-302

18. Jang, H., Reeve, J., \& Deci, E. L. (2010). Engaging students in learning activities: It is not autonomy support or structure but autonomy support and structure. Journal of educational psychology, 102(3), 588

19. Kauser, N., \& Shah, J. H. (2019). An analysis of biological terminology used in textbook of Biology. Journal of Science Education, 1(1), 01-14

20. Kazmi, S. M. A. (2016). Developing quality in secondary education in Pakistan. Available from: https://nation.com.pk/04-Feb-2016/developing-quality-insecondary-education-in-pakistan (Accessed: May 12, 2021)

21. Kemp, H. R. (1984). The concept of energy without heat or work. Physics Education, 19, 234-239

22. Khokhar, F. T. (2008). Evaluation of Text Book of Biology at Secondary Level (M.Phil Thesis), Allama Iqbal Open University, Islamabad, Pakistan

23. Kivirauma, J., \& Laitinen, M. (2014). The changing relationship between disability and education. Arkmedia Oy. Vaasa: The Center for Human Rights of Persons with Disabilities in Finland (VIKE)

24. Kliewer, C., \& Biklen, D. (2001). "School's not really a place for reading": A research synthesis of the literate lives of students with severe disabilities. Journal of the Association for Persons with Severe Handicaps, 26(1), 1-12

25. Kousar, N. (2018). An analysis of Biological Terminology used in Textbook of Biology for class IX. (MS Thesis), Allama Iqbal Open University, Islamabad, Pakistan

26. Kuritz, H. (1981). The popularization of science in nineteenth-century America. History of Education Quarterly, 21(3), 259-274

27. Levin, T., \& Wagner, T. (2006). In their own words: Understanding student conceptions of writing through their spontaneous metaphors in the science classroom. Instructional Science, 34(3), 227

28. Lewis, E. L., \& Linn, M. C. (1996). Where is the heat? A response to David Pushkin. Journal of Research in Science Teaching, 33, 335-337

29. Main, M. (2006). Metacognitive knowledge, metacognitive monitoring, and singular (coherent) vs. multiple (incoherent) model of attachment: Findings and directions for future research. Attachment across the life cycle (pp. 135-167). Routledge

30. Mastropieri, M. A., Scruggs, T. E., \& Graetz, J. E. (2003). Reading comprehension instruction for secondary students: Challenges for struggling students and teachers. Learning disability quarterly, 26(2), 103-116

31. Mclldowie, E. (1995). Energy transfer - Where did we go wrong. Physics Education, 30, 228-230

32. Memon, G. R. (2007). Education in Pakistan: The key issues, problems and the new challenges. Journal of Management and Social Sciences, 3(1), 47-55

33. Merriam-Webster (Nov. 2020). "Cacoepy." Merriam-Webster.com Dictionary, Merriam-Webster, https://www.merriam-webster.com/dictionary/cacoepy. (Accessed 15

34. Mikuláštíková, J. (2012). Teaching Pronunciation at Secondary Level. Master thesis submitted to Univerzita Palackého v Olomouci

35. Nayyar, A. H., \& Dawn Science education in schools. (2016). https://www.dawn.com/news/ 1243391. (Accessed: 16th Nov. 2020)

36. OxfordLanguages. https://languages.oup.com/google-dictionary-en/

37. Pell, T., \& Jarvis, T. (2001). Developing attitude to science scales for use with children of ages from five to eleven years. International Journal of Science Education, 23(8), 847-862

38. Pfundt, O., \& Duit, R. (1994). Bibliography: Students' alternative frameworks and science education (4th ed.). Kiel: Institute for Science Education (IPN, University of Kiel

39. Puryear, J. M. (1995). International education statistics and research: status and problems. International Journal of Educational Development, $15,79-91$. [This paper discusses the problems associated with obtaining reliable education data from national sources.]

40. Pushkin, B. D. (1996). A comment on the need to use scientific terminology appropriately in conception studies. Journal of Research in Science Teaching, 33, 223-224

41. Rani, G. (2000). Measuring change in students attitude towards science over time: An application of latent variable growth modeling. Journal of Science Education and Technology, 9(3), 213-225

42. Raza, W. (2008). Patterns of Pakistani English pronunciation and pedagogic priorities. Retrieved on 9-12-14 from:

Loading [MathJax]/jax/output/CommonHTML/jax.js terns_of_Pakistani_English_pronunciation_and_pedagogic_priorities, 102-112

Page 19/20 
43. Saeed, M. (2007). Education System of Pakistan and the UK: Comparisons in Context to Inter-provincial and Inter-countries Reflections. Bulletin of Education \& Research, 29(2), 43-57

44. Safdar, M. (2007). A Comparative Study Of Ausubelian And Traditional Methods Of Teaching Physics At Secondary School Level In Pakistan. National University Of Modern Languages Islamabad. http://173.208.131.244:9060/xmlui/handle/123456789/6803

45. Schmid, G. B. (1982). Energy and its carriers. Physics Education, 17, 212-218

46. Serrant, T. D., \& McClure, M. W. (2001). Secondary Education Reform: Policy Briefing Paper, 5 pp. Washington, D.C.: World Bank. [This briefing paper describes the World Bank position with respect to secondary education reform and is available at http://www.seryp.org/review/wb.html.]

47. Shafi (2010). A study of the Learning Difficulties in the Subject of Biology at Secondary Level. (Master囚s thesis). University of Education: Multan, Pakistan

48. Shoebottom, P. (2012). The Factors that Influence the Acquisition of a Second Language. A Guide to Learning English, Accessed August $13,2012$. http://esl.fis.edu/teachers/support/factors.htm/

49. Slisko, J. (1994, January). Physics terminology for children and primary school science: Are some standards needed? Paper presented at the winter meeting of the American Association of Physics Teachers, San Diego, CA

50. Slisko, J., \& Dykstra, D. I. Jr. (1997). The role of scientific terminology in research and teaching: Is something important missing? Journal of Research in Science Teaching: The Official Journal of the National Association for Research in Science Teaching, 34(6), 655-660

51. UNESCO (1997). International Standard Classification of Education, 42 pp. Paris: UNESCO. [This publication contains the classification scheme and associated explanations designed to facilitate sharing education statistical data among nations.]

52. UNESCO (2000). World Education Report 2000, 178 pp. Paris: UNESCO. [This publication contains the classification scheme and associated explanations designed to facilitate sharing education statistical data among nations.]

53. UNESCO Institute for Statistics (2000). Facts and Figures 2000, 42 pp. Paris: UNESCO. [This publication contains data and information dealing with secondary education, gender issues, literacy, financing education, and many other aspects of international education.]

54. Warren, J. W. (1982). The nature of energy. European Journal of Science Education, 4, 295-297

55. Warren, J. W. (1983). Energy and its carriers: A critical analysis. Physics Education, 18, 209-212

56. Washton, N. S. (1967). Teaching science creativity. London: W.B Sanders Company

57. Weinburgh, M. (1995). Gender differences in student attitudes toward science: A meta-analysis of literature from 1970 to 1991. Journal of Research in Science Teaching, 32(4), 387-398

58. Wikipedia, S. (2021). https://en.wikipedia.org/wiki/Scientific_terminology (Accessed: May 14,

59. Wiktionary (2019). https://en.wiktionary.org/wiki/cacoepy (Accessed: 15th November, 2020)

60. Wordsense (2020). "cacoepy" in WordSense.eu Online Dictionary. (Accessed: 15th November,

61. Yager, R. (1983). The Importance of Terminology In Teaching K-12 Science. Journal Of Research In Science Teaching, 20(6), 577-588

\section{Figures}

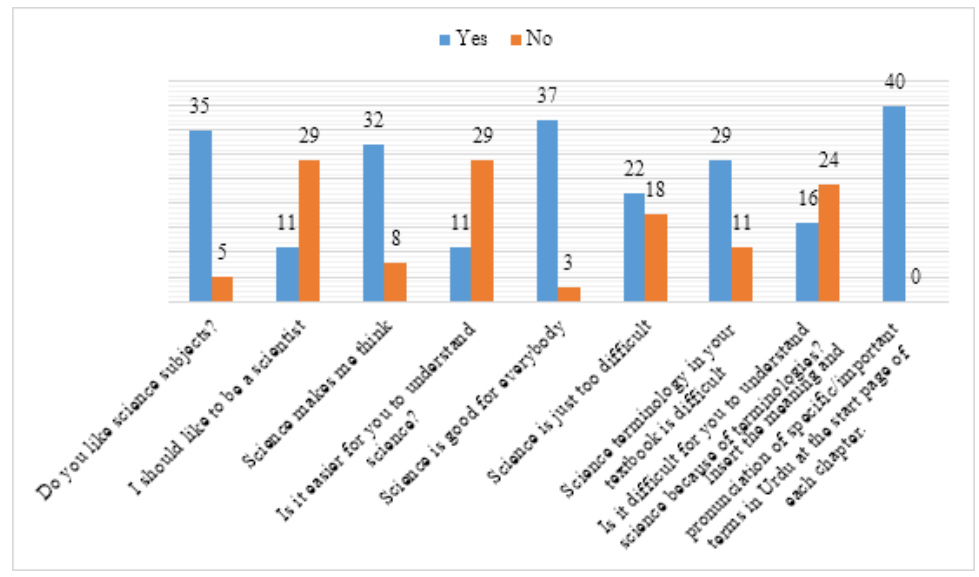

Figure 1

Responses of 40 students chosen at random to the interview questions/statements 